\title{
Water infiltration in the Brazilian tropical savanna: the case of Cerrado típico
}

Felipe Pereira de $\operatorname{Lima}^{\mathrm{a}} \oplus$, Frederico Piontkowski de Souza Almeida ${ }^{a} \oplus$, Sérgio Fernandes Mendonça Filho ${ }^{\mathrm{D}}$, Johnny Rodrigues de Melo Murta ${ }^{\mathrm{a}}{ }^{\odot}$, Gleicon Queiroz de Brito ${ }^{\mathrm{a}}$, Luiz Felippe Salemi ${ }^{\mathrm{a} *}$

${ }^{a}$ Universidade de Brasília, Brasil

*Autor correspondente (lfsalemi@unb.br)

\begin{tabular}{l} 
I N F O \\
\hline Keywords \\
natural vegetation \\
soil hydrology \\
ecohydrology \\
hydrological processes \\
plants
\end{tabular}

\section{Palavras-chaves} vegetação natural hidrologia do solo ecohidrologia processos hidrológicos plantas

\begin{abstract}
A B S T R A C T
The Brazilian savanna, regionally known as Cerrado is an important water source due to its spatial position in the highlands known as Planalto Central of Brazil. Yet, the hydrological functioning of such complex ecosystems and its many variations is poorly understood. In this paper, we characterized the topsoil permeability to water under in one of the most common vegetation types: the Cerrado típico which is a type of savanna. In doing so, we measured infiltration capacity using the Mini-Disk infiltrometer (n $=15)$ and soil resistance to penetration using the Stolf penetrometer $(n=7)$ in a Latossolo (oxisol) under Cerrado típico located in Brasília (Planaltina), Distrito Federal, Brazil. Our results indicated a high infiltration capacity under Cerrado típico which is potentially associated with a low penetration resistance. This fact might highlight the importance of the natural undisturbed ecosystems, in this case Cerrado típico, as a land-cover which favors hydrological processes which, in turn, promotes soil-groundwater recharge that are inportant to maintain water bodies and reservoirs in the region.
\end{abstract}

\section{R E S U M O}

Infiltração de água na savana tropical brasileira: o caso do Cerrado típico

A savana brasileira, regionalmente conhecida como Cerrado é uma importante fonte de água devido à sua posição espacial na região de terras de alta altitude conhecida como Planalto Central do Brasil. No entanto, o funcionamento hidrológico desse complexo conjunto de ecossistemas e de suas inúmeras variações é pouco compreendido. O objetivo do presente estudo foi caracterizar a permeabilidade da superfície do solo à água em um dos mais comuns tipos de vegetação do Cerrado: o Cerrado típico que é um tipo de savana. Foram medidas a capacidade de infiltração usando o infiltrômetro Mini-Disk $(n=15)$ e a resistência do solo à penetração usando o penetrômetro Stolf $(n=7)$ em um Latossolo sob Cerrado típico localizado em Brasília (Planaltina), Distrito Federal, Brasil. Os resultados indicaram uma alta capacidade de infiltração sob Cerrado típico que pode estar associada à uma baixa resistência do solo à penetração. Este fato destaca a importância dos ecossistemas naturais sem distúrbio, no presente caso o Cerrado típico, como uma cobertura da terra que favorce processos hidrológicos que promovem a recarga de água no solo e de água subterrânea que mantém a água nos corpos d’água e reservatórios da região. 


\section{INTRODUCTION}

The Brazilian savanna, regionally known as Cerrado, is composed by a variety of forests, grasslands and savannas (Castro e Kauffmann, 1998). However, as its name suggests, the main vegetation type is savanna. These savannas are not similar in terms of woody components density (Furley, 1999). For example, Cerrado, which is also the term used to describe the most abundant savanna type, comprises at least three variation with regards to woody components density (Ribeiro e Walter, 2008), that is, (i) Cerrado ralo (savanna with low density of woody components), (ii) Cerrado denso (savanna with high density of woody components) and (iii) Cerrado típico (savanna with moderate density of woody components).

Cerrado is widely distributed within Brazil. Though massive land-use change has been taken place within this biome (Strassburg et al., 2017), original area is estimated to be in the order 2 million $\mathrm{km}^{2}$ (Ratter et al., 1997). This means that Cerrado covers a large extent of important river-basins. For example, Tocantins-Araguaia, São Francisco and Paraná have their springs within the Cerrado biome (Lima e Silva, 2005; Lima, 2011). Although, natural ecosystems are considered to play an important role in protecting the water of such basins, few precise basic information is available with respect to soil permeability of the Cerrado. From the available data, few have precisely described the exact type of vegetation under which measurements have been taken. As shown earlier, this description in insufficient if the hydrological functioning of the different types of vegetation (frequently called "phytophysiognomies") is required to better understand the types of Cerrado. Furthermore, the few publications regarding soil permeability used a number of samples sufficient to properly describe hydraulic properties variability (Brito, 2019). Generally, a high number of samples $(n \geq 15)$ is necessary to characterize such properties that vary in space (Bonell et al., 2010; Salemi et al., 2020).

Understading soil permeability to water is crucial to comprehend the hydrological functioning of the Cerrado and, as a consequence, the ecosystem (hydrological) services they provide. In this respect, infiltration is one of the most relevant hydrological processes in order to allow soilgroundwater recharge which is necessary to maintain the dry season flow in rivers. The objective of the present paper was to characterize the soil surface permeability to water under a savanna type vegetation (Cerrado típico).

\section{MATERIAL AND METHODS}

\section{Study area}

We used an area of Cerrado típico (savanna with moderate density of woody components) located within the campus Planaltina of the University of Brasília (Figure 1). The site is located in Brasília (Planaltina region), Distrito Federal, Brazil in the following coordinates: $15^{\circ} 35^{\prime} 59.48^{\prime \prime} \mathrm{S}$ and 47³9'28.90”'O.
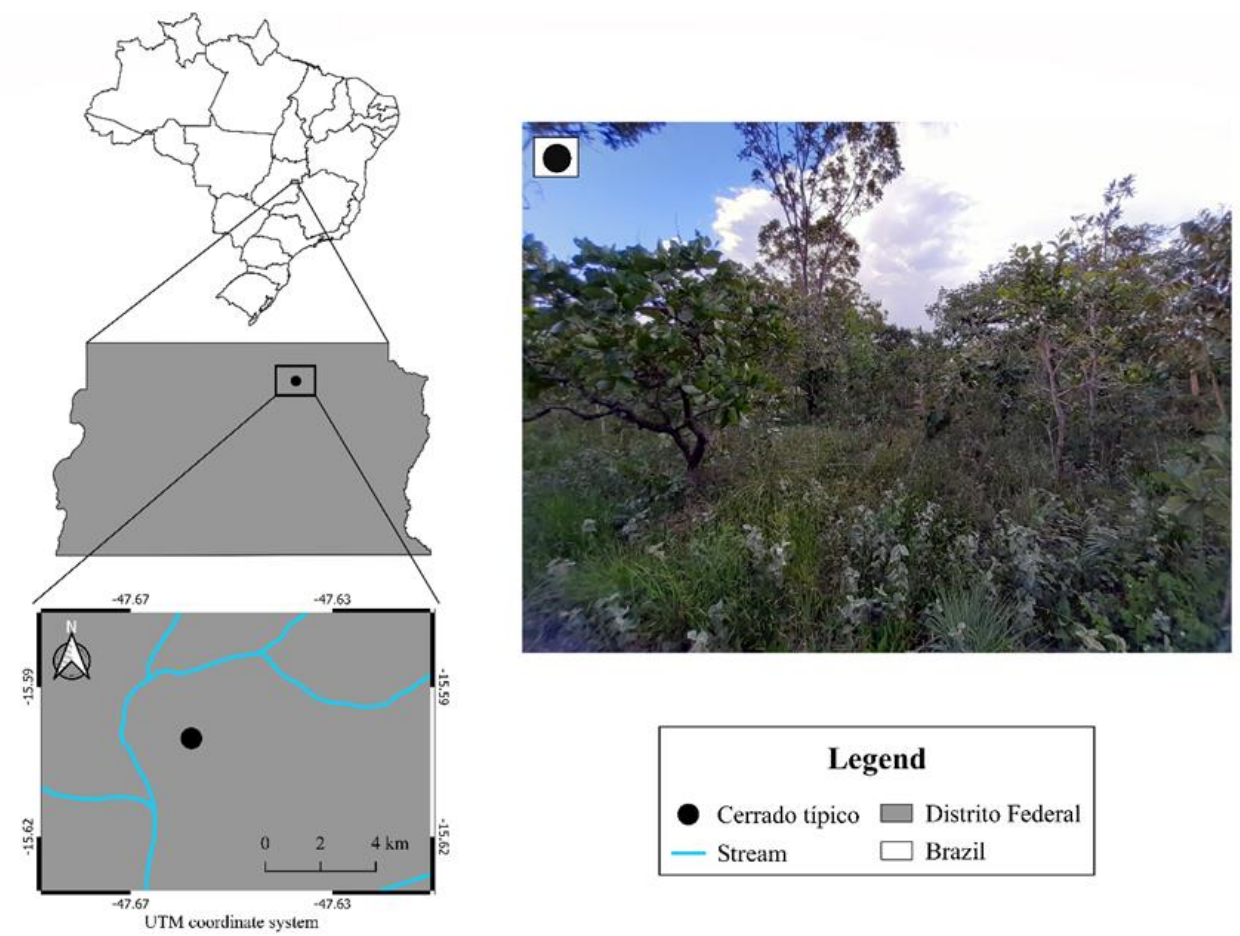

Figure 1 - Location of the study area. 
Regarding pedology, the soil type is a Latossolo Vermelho-Amarelo (Brazilian classification system) or Oxisol (US Soil taxonomy) or Ferralsol (FAO). Texture is classified as clayey (J.V. Bernardi, personal communication).

The climate of the region is markedly seasonal. Annual rainfall is around $1393 \mathrm{~mm}$ (Malaquias et al., 2010). Wet season (October to April) generally presents nearly $100 \%$ of rainfall (Malaquias et al., 2010).

The vegetation is described as Cerrado típico which, as shown earlier, is a type of savanna where trees and shrubs are present at moderate density when compared to other forms of Cerrado (Ribeiro e Walter, 2008). Cerrado típico (in english "Typical Cerrado") means that it is the most abundant type of savanna of the Cerrado biome.

\section{Variables and sampling design}

Infiltration capacity have been measured using Mini disk infiltrometer (Decagon Devices). Such device is a type of tension-infiltrometer which operates from 0 to $-7 \mathrm{~cm}$ suction rate and uses the mathematical solution proposed by Zhang (1997) to calculate the hydraulic conductivity. In the present paper, aiming to estimate infiltration capacity, $0 \mathrm{~cm}$ suction rate has been adopted. In order to improve the contact of the infiltrometer with the soil, we used a thin layer of sand. Measurements have been taken at constant time intervals until a steady infiltration rate had been found for at least 3 times consecutively. We sampled 15 points in two linear transects following contour lines (Figure 2). The mean distance between each sampling point was 2 $\mathrm{m}$.

In order to clarify indirectly soil porosity and bulk density, soil penetration resistance was measured using the Stolf impact penetrometer (Kamaq). Such device operates using $2 \mathrm{~kg}$ weight which drives a metal tap into to the soil (Stolf et al., 2012). We arbitrarily selected four impacts to measure soil resistance. Seven sampling units have been chosen randomly within the area of infiltration linear transects (Figure 2). Aiming to avoid interference of soil moisture content on soil penetration resistance, measurements have been performed during the dry season.

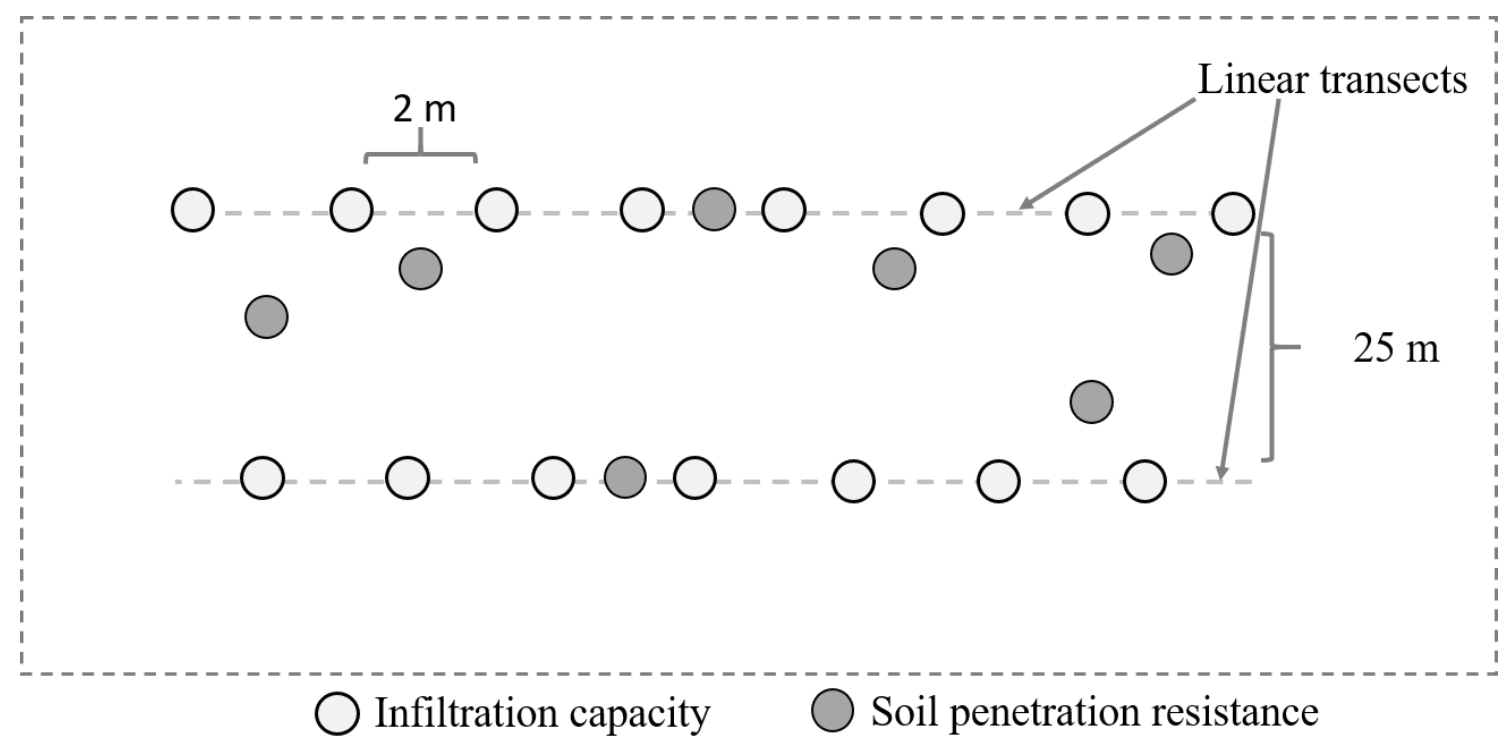

Figure 2 - Sampling design used to sample infiltration capacity (white circles) and soil resistance to penetration (gray circles). Not scaled for simplicity.

\section{Analysis}

Descriptive statistics have been used to present the observations. In order to evaluate if the number of samples were sufficient to properly characterize soil infiltration capacity variability, we carried out the sufficiency analysis provided by Salemi et al. (2020) in which a sufficient number of samples is considered met when variability statistics reached a relatively stable (i.e. $\leq 5 \%$ ) value for, at least, three times consecutively. As our infiltration data followed the normal distribution, we used standard deviation as the variability statistics. Our data was tested for normality using PAST software at $\alpha<$ 0.05 (Hammer et al., 2001).

\section{RESULTS AND DISCUSSION}

Infiltration capacity was estimated as $716 \pm 222$ mm.hr-1 (mean \pm standard deviation). A high variability could be detected (Figure 3). The number of samples collected suffice following the 
criterion established by Salemi et el. (2020). That is, varability statistics stabilised as the number of samples increased (Figure 4). Soil presented a low resistance to penetration along all impacts (Figure $5)$.

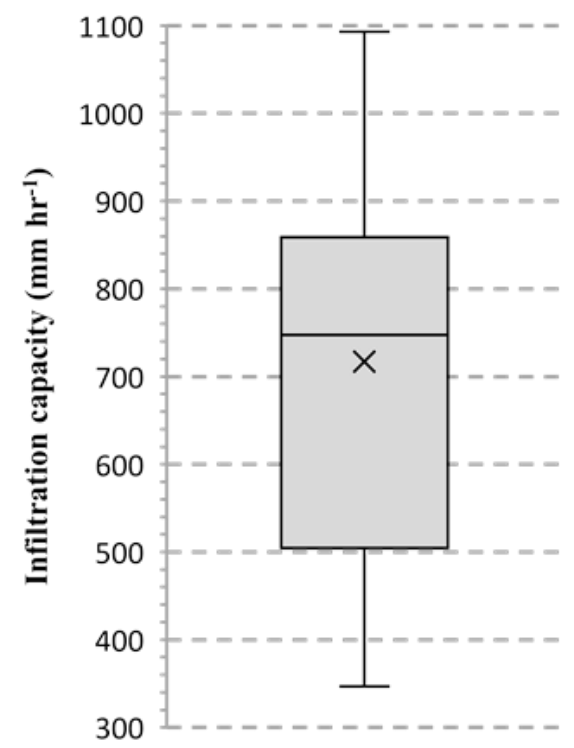

Figure 3 - Box-plot of infiltration capacity in soil under Brazilian tropical savanna (Cerrado típico). The length of the box represents the sample interquartile range; the bar in the box is the median whereas the $\mathrm{x}$ represents the mean. The extremes of the vertical lines outside the box represents the minimum and maximum observed values.

The infiltration capacity of the soil under Cerrado típico was considered rapid ( $\geq 254 \mathrm{~mm} . \mathrm{hr}^{-}$
1) based on Soil Survey Staff (1993) standard. When comparing among natural ecosystems, it is within the order of magnitude of those observations carried out in the Brazilian tropical savanna documented by Souza and Alves (2003) and an order of magnitude lower compared to those by Hunke et al. (2015) (Table 1). Compared to forest ecosystems such as those of the Amazon, our infiltration estimate is also one order of magnitude lower (Zimmermann et al., 2006; Scheffler et al., 2011) (Table 1).

We hypothesize that differences in woody components density between forests and savannas and even within the savanna group (Cerrado denso vs. cerrado típico) may explain such differences. Thus, though no information on the type of "natural Cerrado" is available in Hunke et al. (2015), we suggest it was probably a Cerrado denso. In ecosystems with higher woody density, a higher biomass below and aboveground (Castro e Kauffmann, 1998) would promote higher biological activity (root growth and decay, higher litterfall, decomposition). These process may contribute to a high porosity already documented in Latossolos (Araújo et al., 2004) and observed here through our penetrometer assays. In addition, a less marked dry season in the Amazon forest would also enhance such differences through the promotion of the continuity of those biological processes since under marked dry season, as the one under our Cerrado típico region (Malaquias et al., 2010), those process may diminish with water limitation (Nardoto e Bustamante, 2003; Valenti et al., 2008).

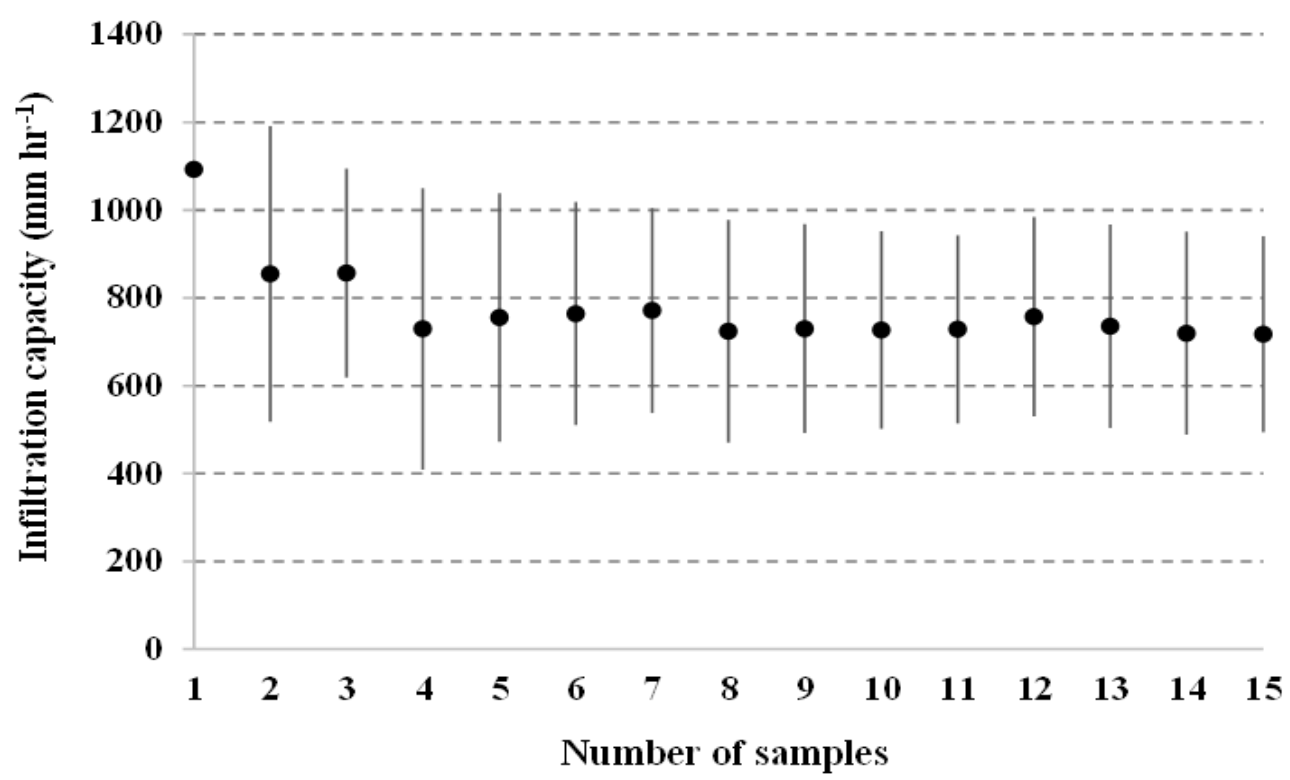

Figure 4 - Mean (circles) and standard deviation (bars) as a function of the number of samples. 


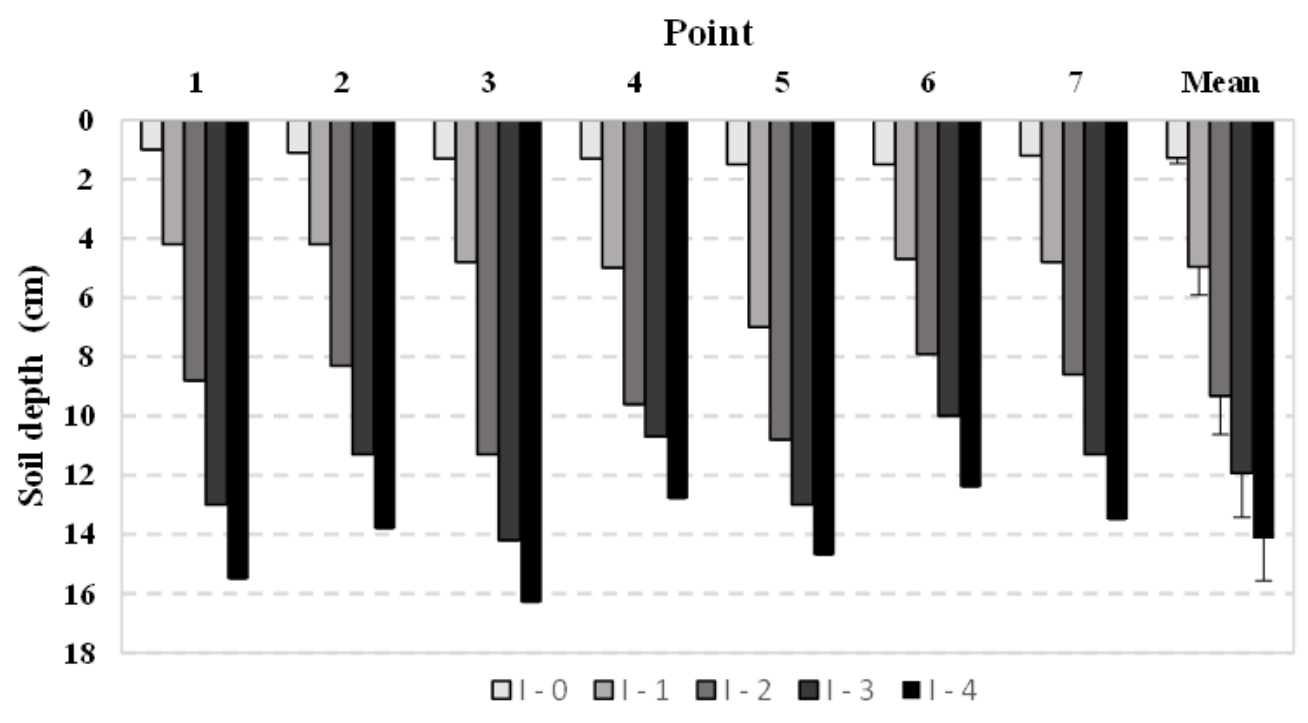

Figure 5 - Soil resistance to penetration in each of the seven points samples during impacts 0 to 4 . On the right, the mean and standard deviation (bars) of all sampling points.

Finally, the infiltration capacity observed here is likely to exceed the maximum rainfall intensities of the region. For example, the highest 60-minute rainfall intensity recorded at Estação Ecológica das Águas Emendas Metereological Station in 2019 (located $5 \mathrm{~km}$ distant from our Cerrado típico site) was $56 \mathrm{~mm} \cdot \mathrm{hr}^{-1}$. Though there was no finer resolution record to estimate higher rainfall intensities, assuming the heaviest convective events available in Salemi et al. (2013) and Moraes et al. (2006) which were $105 \mathrm{~mm} \cdot \mathrm{hr}^{-1}$ and 80 $\mathrm{mm} . \mathrm{hr}^{-1}$ respectively, even our lowest infiltration capacity observation $\left(340 \mathrm{~mm} \cdot \mathrm{hr}^{-1}\right.$ see Figure 1) was clearly higher than those rainfall intensities. This fact might highlight the importance of the natural undisturbed ecosystems, in this case Cerrado típico, as a land-cover which favors hydrological processes which, in turn, promotes soil-groundwater recharge that are inportant to maintain water bodies and reservoirs in the region. That is not the case of other land-uses such as soy and pasture which, demonstrably decrease infiltration capacity (Araújo et al., 2007; Bono et al., 2012; Hunke et al., 2015) favoring erosion and, as a consequence, land degradation (Montgomery, 2007).

Table 1 - Median of infiltration capacity from various studies that measured it in conditions similar to the present study

\begin{tabular}{|c|c|c|c|c|c|}
\hline Reference & Method & Soil type & City/Region & Vegetation & $\begin{array}{c}\text { Central tendency } \\
\left(\mathbf{m m} \cdot \mathbf{h r}^{-1}\right)\end{array}$ \\
\hline $\begin{array}{l}\text { Present } \\
\text { study }\end{array}$ & $\begin{array}{l}\text { Mini-Disk } \\
\text { infiltrometer }\end{array}$ & $\begin{array}{l}\text { Latossolo Ver- } \\
\text { melho-Amarelo }\end{array}$ & $\begin{array}{l}\text { Brasília (Planaltina), } \\
\text { Distrito Federal, Brazil }\end{array}$ & $\begin{array}{l}\text { Savanna (Cer- } \\
\text { rado típico) }\end{array}$ & 716 \\
\hline Brito (2019) & $\begin{array}{l}\text { Mini-Disk } \\
\text { infiltrometer }\end{array}$ & $\begin{array}{l}\text { Latossolo Ver- } \\
\text { melho-Amarelo }\end{array}$ & $\begin{array}{c}\text { Brasília (Lago Sul), } \\
\text { Distrito Federal, Brazil }\end{array}$ & $\begin{array}{l}\text { Savanna (Cer- } \\
\text { rado típico) }\end{array}$ & 697 \\
\hline $\begin{array}{l}\text { Hunke et al. } \\
(2015)\end{array}$ & $\begin{array}{l}\text { Single ring } \\
\text { infiltrometer }\end{array}$ & $\begin{array}{l}\text { Latossolo Ver- } \\
\text { melho }\end{array}$ & $\begin{array}{c}\text { Jaciara, Mato Grosso } \\
\text { State, Brazil }\end{array}$ & $\begin{array}{l}\text { Savanna (Cer- } \\
\text { rado) }\end{array}$ & 1,200 \\
\hline $\begin{array}{l}\text { Souza and } \\
\text { Alves (2003) }\end{array}$ & $\begin{array}{l}\text { Double ring } \\
\text { infiltrometer }\end{array}$ & $\begin{array}{l}\text { Latossolo Ver- } \\
\text { melho }\end{array}$ & $\begin{array}{c}\text { Selvíria, Mato Grosso } \\
\text { do Sul, Brazil }\end{array}$ & $\begin{array}{l}\text { Savanna (Cer- } \\
\text { rado) }\end{array}$ & 300 \\
\hline $\begin{array}{l}\text { Scheffler et } \\
\text { al. (2011) }\end{array}$ & $\begin{array}{l}\text { Hood infil- } \\
\text { trometer }\end{array}$ & $\begin{array}{l}\text { Latossolo Ver- } \\
\text { melho-Amarelo }\end{array}$ & $\begin{array}{c}\text { Canarana, Mato Grosso } \\
\text { State, Brazil }\end{array}$ & $\begin{array}{c}\text { Transition } \\
\text { Tropical For- } \\
\text { est } \\
\end{array}$ & 1,200 \\
\hline $\begin{array}{l}\text { Zimmer- } \\
\text { mann et al. } \\
(2006)\end{array}$ & $\begin{array}{l}\text { Hood infil- } \\
\text { trometer }\end{array}$ & Argissolo & Rondônia State, Brazil & $\begin{array}{l}\text { Tropical For- } \\
\text { est }\end{array}$ & 1,690 \\
\hline
\end{tabular}


In order to predict the flowpath of the water that infiltrates the soil, observations of percolation are needed at higher soil depth. The only study which reported percolation capacity was by Hunke et al. (2015) who measured such property at 0.14, 0.2 and $0.4 \mathrm{~m}$. Given that Latossolos (Oxisols) are deep soils (>> $2 \mathrm{~m}$ ), there is a clear gap to be bridged in future research. Likewise, though Latossolos are the most abundant soil type within the Cerrado biome (Reatto et al., 2003; Reatto e Martins, 2005), the savannas like Cerrado típico also occur in other different types of soils such as Entisols, Inceptisols, and Plinthic soils (Ribeiro e Walter, 2008). This may provide interesting opportunity to understand differences in near-surface hydrological processes in the same type of savannas under different soils.

\section{CONCLUSION}

The present study carried out an assessment of topsoil permeability under Cerrado típico, the most abundant type of savanna of the Cerrado biome (Brazil). We showed a remarkably high infiltration which probably accomodates the highest rainfall intensities in the region. This finding demonstrates the hydrological importance of the Cerrado típico in terms of promoting ecosystem services related to soil, groundwater and also biological conservation.

\section{ACKNOWLEDGEMENTS}

The authors would like to thank the Programa de Iniciação Científica of Decanato de Pós--graduação (Universidade de Brasília) which provided the financial support and opportunity of the scientific initiation of the first and second authors.

\section{REFERENCES}

Araújo MA, Tormena CA, Silva AP. Propriedades físicas de um Latossolo Vermelho distrófico cultivado e sob mata nativa. Revista Brasileira de Ciência do Solo, v.28, p.337345, 2004.

https://doi.org/10.1590/S0100-06832004000200012

Araújo R, Goedert W, Lacerda, M. Qualidades de um solo sob diferentes uso e sob Cerrado nativo. Revista Brasileira de Ciência do Solo, v.31, n.5, p.1099-1108, 2007. https://doi.org/10.1590/S0100-06832007000500025

Bonell M, Purandara BK, Venkatesh B, Krishnaswamy J, Acharya HAK, Jayakumar R, Singh UV, Chappell, N. The impacts of forest use and reforestation on soil hydraulic conductivity in the Western Ghats of India: implications for surface and sub-surface hydrology. Journal of Hydrology, v.391, n.1-2, p.47-62, 2010.

https://doi.org/10.1016/j.jhydrol.2010.07.004

Bono JAM, Macedo MCM, Tormena CA, Nanni MR, Gomes EP, Muller MML. Infiltração de água no solo em um latossolo vermelho da região sudoeste dos cerrados com diferentes sistemas de uso e manejo. Revista Brasileira de Ciência do Solo, v.36, n.6, p.1845-1853, 2012. https://doi.org/10.1590/S0100-06832012000600019

Brito GQ. Capacidade de infiltração de água no solo em fitofisionomias do bioma Cerrado. Ano de obtenção: 2019. 43p. Dissertação (Mestrado em Ciências Ambientais) Universidade de Brasília, Brasília.

Castro EA, Kauffman JB. Ecosystem structure in the Brazilian Cerrado: a vegetation gradient of aboveground biomass, root mass and consumption by fire. Journal of Tropical Ecology, v.14 n.3, p.263-283, 1998.

https://doi.org/10.1017/S0266467498000212

Furley PA. The nature and diversity of neotropical savana vegetation with particular reference to the Brazilian Cerrados. Global Ecology and Biogeography, v.8, p.223-241, 1999.

https://doi.org/10.1046/j.1466-822X.1999.00142.x

Hammer O, Harper DAT, Ryan PD. PAST: Paleontological Stastitics software package for education and data analysis. Palaeontologia Electronica, v.4, n.1, p.1-9, 2001.

Hunke P, Roller R, Zeihofer P, Schröder B, Mueller EN. Soil changes under different land-uses in the Cerrado of Mato Grosso, Brazil. Geoderma Regional, v.4, p.31-43, 2015. https://doi.org/10.1016/j.geodrs.2014.12.001

Lima JEFW, Silva EM. Estimativa de produção hídrica superficial do Cerrado brasileiro. In: Scariot, A., Sousa-Silva, JC., Felfili, JM. (Orgs.). Cerrado: ecologia, biodiversidade e conservação. Brasília: Ministério do Meio Ambiente, p.61-72, 2005 .

Lima, JEFW. Situação e perspectivas sobre as águas do cerrado. Ciência e cultura, v.63, n.3, p.27-29, 2011. http://dx.doi.org/10.21800/S0009-67252011000300011

Malaquias JV, Silva FAM, Evangelista BA. Precipitação pluviométrica em Planaltina - DF: análise de dados da estação principal da EMBRAPA Cerrados. Planaltina - DF: EMBRAPA Cerrados, 2010. 15p.

Montgomery DR. Soil erosion and agricultural sustainability. Proceedings of the National Academy of Sciences, v.104, n.33, p.13268-13272, 2007. https://doi.org/10.1073/pnas.0611508104

Moraes JM, Schuler AE, Dunne T, Figueiredo RO, Victoria RL. Water storage and runoff processes in plinthic soils under forest and pasture in Eastern Amazonia. Hydrological Processes, v.20, p.2509-2526, 2006. https://doi.org/10.1002./hyp.6213

Nardoto GB. Bustamante, MMC. Effects of fire on soil nitrogen dynamics and microbial biomass in savannas of Central Brazil. Pesquisa Agropecuária Brasileira, v.38, n.8, p.955-962, 2003. https://doi.org/10.1590/S0100-204X2003000800008

Ratter JR, Ribeiro JF, Bridgewater S. The Brazilian Cerrado Vegetation and Threats to its biodiversity. Annals of Botany, v.80, n.3, p.223-230. https://doi.org/10.1006/anbo.1997.0469

Reatto A, Martins ES, Cardoso EA, Spera ST, Carvalho Júnior OA, Guimarães R, Farias MFR, Silva AV. Solos e princiapais fitofisionomias do Alto curso do rio Descoberto, Distrito Federal e Goiás. Boletim de Pesquisa e Desenvolvimento, 28p., 2003. 
Reatto A, Martins ES. Classes de solo em relação aos controles da paisagem do bioma Cerrado. In: Scariot, A., SousaSilva, JC., Felfili, JM. (Orgs.). Cerrado: ecologia, biodiversidade e conservação. Brasília: Ministério do Meio Ambiente, p.47-59, 2005.

Ribeiro JF, Walter BMT. As principais fitofisionomias do Bioma Cerrado. In: Sano, SM., Almeida, SP., Ribeiro, JF. (Eds.). Cerrado: Ecologia e Flora. Brasília. Brasília: Embrapa Cerrados, p.151-212, 2008.

Salemi LF, Fernandes RP, Silva RWC, Garcia LG, Moraes JM, Groppo JD, Martinelli LA. Soil hydraulic properties: a simple and practical approach to estimate the number of samples. Eurasian Journal of Soil Science, v.9, n.1, p.1823, 2020. https://doi.org/10.18393/ejss.629344

Salemi LF, Groppo JD, Trevisan R, Moraes JM, Ferraz SFB, Villani JP, Duarte-Neto PJ, Martinelli LA. Land-use change in the Atlantic forest region: consequences for the hydrology of small catchments. Journal of Hydrology, v.499, p.100-109, 2013.

https://doi.org/10.1016/j.jhydrol.2013.06.049

Scheffler R, Neill C, Krusche AV, Elsenbeer H. Soil hydraulic response to land-use change associated with the recent soybean expansion at the Amazon agricultural frontier. Agriculture, Ecosystems and Environment, v.144, p.281-298, 2011.

https://doi.org/10.1016/j.agee.2011.08.016

Soil Survey Staff. Soil survey manual. Washington, USDASCS. U.S. Gov. Print. Office. 437p. 1993.

Souza ZM, Alves MC. Movimento de água e resistência à penetração em um Latossolo Vermelho distrófico de cerrado, sob diferentes usos e manejos. Revista Brasileira de Engenharia Agrícola e Ambiental, v.7, n.1, p.18-23, 2003.

Stolf R, Murakami JH, Manier MA, Soraes MR, Silva LCF. Incorporação de régua para medida de profundiade no projeto do penetrômetro de impacto Stolf. Revista Brasileira de Ciência do Solo, v.36, p.1476-1482, 2012. https://doi.org/10.1590/S0100-06832012000500011

Strassburg BBN, Brooks T, Feltran-Barbieri R, Iribarrem A, Crpuzeilles R, Loyoloa R, Latawiec AE, Oliveira-Filho FJB, Scaramuzza CAM, Scarano FR, Soares-Filho B, Balmford A. Moment of the Truth for the Cerrado hotspot. Nature Ecology e Evolution, v.1, p.099, 2017. https://doi.org/10.1038/s41559-017-0099

Valenti MW, Cianciaruso MV, Batalha MA. Seasonality of litterfall and leaf decompostion in a Cerrado site. Brazilian Journal of Biology, v.68, n.3, p.459-465, 2008.

Zhang R. Determination of soil sorptivity and hydraulic conductivity from the disk infiltrometer. Soil Science Society of American Journal, v.61, n.4, p.1024-1030, 1997. https://doi.org/10.2136/sssaj1997.03615995006100040005 $\mathrm{x}$

Zimmermann B, Elsenbeer H, Moraes JM. The influence of land-use changes on soil hydraulic properties: implications for runoff generation. Forest Ecology and Management, v.222, v.1-3, p.29-38, 2006.

https://doi.org/10.1016/j.foreco.2005.10.070 